\title{
Deltaic floodplains development and wetland ecosystems management in the Ganges-Brahmaputra-Meghna Rivers Delta in Bangladesh
}

\author{
Shafi Noor Islam ${ }^{1}$
}

Received: 17 November 2015/ Accepted: 13 March 2016/Published online: 7 April 2016

(C) Springer International Publishing Switzerland 2016

\begin{abstract}
The Ganges delta has a great importance for its exceptional hydro-geological settings and deltaic floodplain wetland ecosystems. The floodplain is formed by the deposition of the Ganges, Brahmaputra and Meghna River. The physical characteristics of floodplains, geographic location, the multiplicity of rivers and the monsoon climate render wetland ecosystems highly vulnerable to natural disaster and anthropogenic activities. Flooding is a natural annual phenomenon of a river system which occupies a unique position in the culture, society and economy of Bangladesh. There are 257 rivers in Bangladesh, from which 59 rivers are transboundary rivers. All of these rivers play a prospective role in the economic development of the country. The deltaic floodplains of the Ganges-Brahmaputra-Meghna Rivers Delta are undergoing rapid hydromorphological changes due to natural and anthropogenic causes. Historically, these three rivers have played a strong role in formation of deltaic floodplains and wetland ecosystems in the Ganges-Brahmaputra-Meghna (GBM) Rivers Delta. The GBM rivers system is continuously developing the active deltaic floodplains in the coastal region of Bangladesh. The deltaic wetlands are under threat due to extension of agricultural land use, shrimp cultivation, and saline water intrusion in the tidally active delta region. The main reasons of ecosystem degradation are the settlements development, urbanization processes and substantial uses of deltaic natural resources. The study
\end{abstract}

Shafi Noor Islam

shafinoor@yahoo.com; shafi.islam@ubd.edu.bn

1 Department of Geography and Development and Environmental Studies, Faculty of Arts and Social Sciences (FASS), Universiti Brunei Darussalam (UBD), Jalan Tungku Link, Gadong, Bandar Seri Begawan BE 1410,, Brunei Darussalam investigated the role of river systems in the formation and development process of delta and salinity intrusion and its impact on wetland ecosystems in the tidally active deltaic floodplains in the coastal region. The objective of this study is to understand the role of river systems in the delta formation process and an analysis of deltaic floodplain and degraded wetland ecosystems of the Ganges-Brahmaputra-Meghna Rivers Delta in Bangladesh.

Keywords Ganges-Brahmaputra-Meghna Delta $\cdot$ River system · Floodplain formation - Wetland ecosystems management

\section{Introduction}

The Ganges-Brahmaputra-Meghna River Delta is the largest delta in the world and it is located in the Bengal basin of the South Asian region of Bengal (Morgen and Mclntire 1959; Khandoker 1987; Sarker et al. 2003; Goodbred and Nicholls 2004). The delta is the most fertile and vegetated alluvial land. It is called "Green Delta" which is the "nickname" for Bangladesh (Islam 2006). The Ganges delta is also called the Ganges-Brahmaputra-Meghna (GBM) River Delta, or Bengal delta, or Ganges-Brahmaputra (GB) river delta (Bagchi 1944; Coleman 1969; Rob 1998; Goodbred and Nicholls 2004; Woodroffe et al. 2006; Islam 2006). The delta developed and came into existence through sediment deposition of the three mighty rivers in Bangladesh; the Ganges, the Brahmaputra, and the Meghna (Goodbred and Kuehl 1999; Goodbred and Nicholls 2004; Islam and Gnauck 2008). The Ganges-BrahmaputraMeghna (GBM) Delta is situated just above the Bay of Bengal. In most of the Bengal basin, including the coastal zone and offshore areas, compaction or isostatically 
induced subsidence occurs (Bagchi 1944; Goodbred and Keuhl 1999). The river courses in the deltaic region are broad, active and carry enormous amount of water and sediments $\left(10^{9} \mathrm{t} / \mathrm{year}\right)$ in forming and enlarging the Ganges delta (Sarker et al. 2003; Islam and Gnauck 2008). This delta is a tract of vast alluvial flat roughly bordering on the Greek letter " $\Delta$ " (Delta) and commences at the off take of the Bhagirathi River near Gaur of Malda district in West Bengal, India (Bagchi 1944; Coleman 1969; Rob 1998; Goodbred and Nicholls 2004; Woodroffe et al. 2006). The silt deposits of the delta cover an area of about $115,000 \mathrm{~km}^{2}$ in Bangladesh and West Bengal of India (Bagchi 1944; Coleman 1969; Goodbred and Nicholls 2004; Woodroffe et al. 2006). It comprises part of the area of Rajshahi district, Pabna, Kushtia, Meherpur, Chuadanga, Jessore, Jhenaidah, Magura, Norail, Khulna, Satkhira, Bagerhat, Rajbari, Faridpur, Gopalgonj, Sariatpur, Barisal, Patuakhali, Borguna, Jhalokati, Pirozpur, Bhola Noakhali, Luxmipur, Manikganj and part of the Munshiganj district of Bangladesh as well as a major portion of West Bengal in India (Rob 1998; Islam and Gnauck 2008). The silts and sediments are carried by the normal flow and annual flooding of the rivers and as a result the delta continues to expand. Four major cities such as Calcutta, Khulna, Jessore, Faridpur and Barisal are situated in the Ganges delta (Islam 2001; Goodbred and Nicholls 2004) (Fig. 1) with a total population of about 150 million.

The major rivers play a large role in the development of the Ganges-Brahmaputra-Meghna Delta and protect the deltaic floodplains and wetland ecosystems in Bangladesh (Islam 2001; Khan and Islam 2008). The Ganges (Padma) and Brahmaputra (Jamuna) Rivers carry fresh water and sediment loads to the catchment area in the downstream and contribute in developing deltaic floodplains. The deltaic morphology of southern regions of Bangladesh is characterized by its funnel shaped vast network of rivers, strong tides and wind action and enormous river discharge laden with bed and suspended sediments (Bagchi 1944; EGIS 2000; Sarker et al. 2003; Islam and Gnauck 2009a).

The alluvial deltaic floodplain developed at the southern portion of the Bengal basin which is about $360 \mathrm{~km}$ wide along the Bay of Bengal (Goodbred and Kuehl 2000, Allee et al. 1949). The river courses in the delta are broad, active and dynamic. Annually, the rivers carry about 6 million $\mathrm{m}^{3} / \mathrm{s}$ water flows and 2.4 billion tons of sediment into the Bay of Bengal (Anwar 1988). The landscapes of the deltaic region encompass strong aesthetic, cultural, biological and geological values (Zube 1986). The coastal landscape has a continuous erosion and depositional action which is illustrated in Fig. 1. The deltaic coastal landscapes of the Ganges mouth area are undergoing rapid hydro-morphological and ecological change due to natural geomorphic processes and human influences on the landscapes (Fig. 1). The total area of wetlands in Bangladesh estimate between 70,000 and $80,000 \mathrm{~km}^{2}$, i.e., about $50 \%$ of the total land surface (Akonda 1989; Khan et al. 1994). These include rivers, estuaries, mangrove swamps, marsh (haors), baor (fresh water oxbow lake) and beels (deprest land), water reservoirs, and some other low lands, which are seasonally inundated to a depth of $30 \mathrm{~cm}$ or more (Khan et al. 1994; Hughes et al. 1994; Gopal and Wetzel 1995; Islam and Gnauck 2008). In the Ganges-Brahmaputra-Meghna

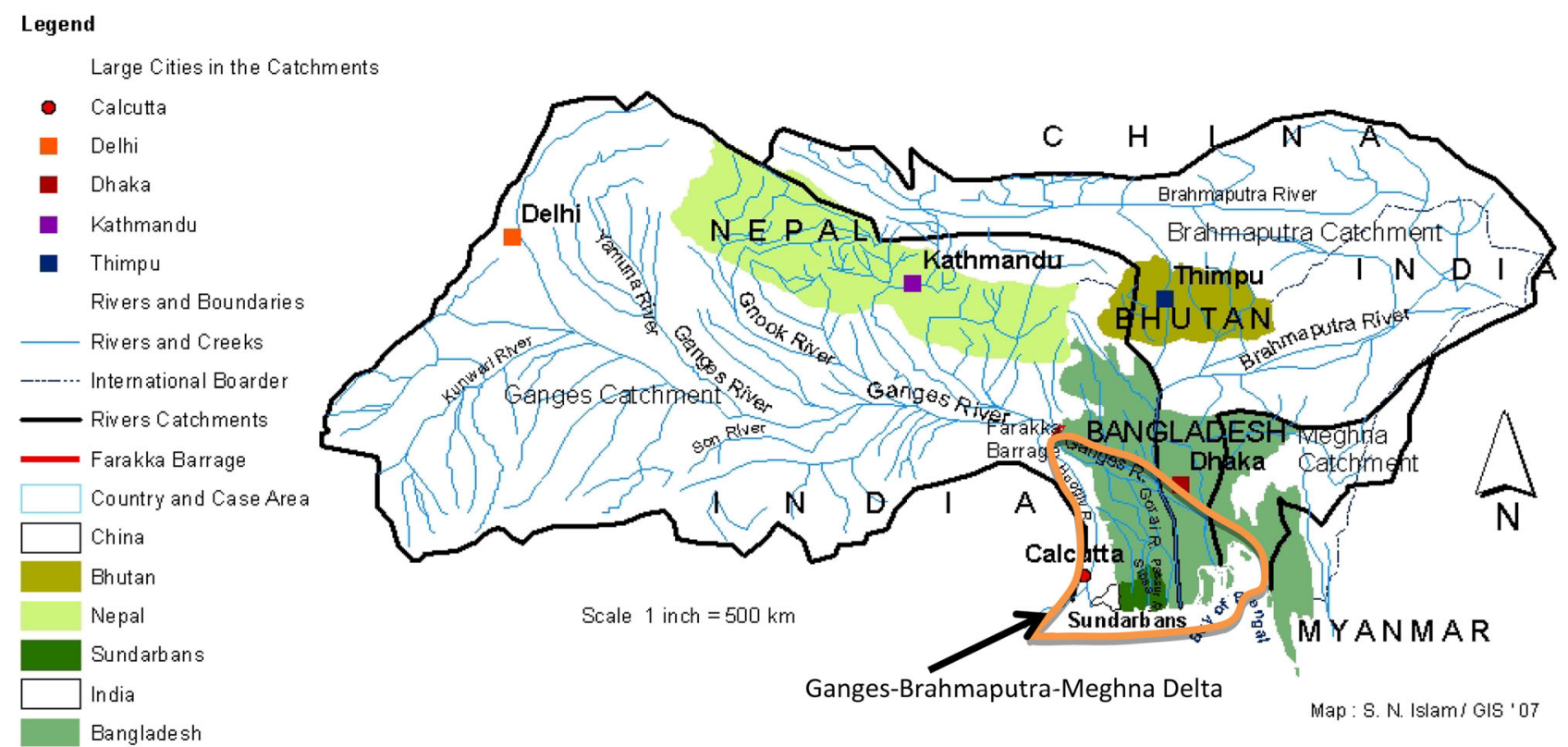

Fig. 1 Geographical location of the Ganges-Brahmaputra-Meghna Delta and the GBM catchments (Source: after Islam and Gnauck 2008) 
Rivers floodplain alone, approximately 2.1 million ha of wetlands have been lost due to flood control, drainage and irrigation development (Khan et al. 1994). There are 12 major freshwater and saline water wetlands (haors and baors) located in the Ganges delta. Most of these wetlands are under threat owing to substantial uses and unethical management of natural resources in the Ganges deltaic floodplains regions (Sarker 1993; Ahmed et al. 2008). The southern coastal wetlands of the delta are tidally active, which is polluted by saline water intrusion and penetration. The livelihoods and ecology of the Ganges delta of Bangladesh portion depends on the Ganges fresh water supply in the downstream (Rahman 1988; Khan et al. 2004). Therefore, deltaic wetlands are facing serious challenges from environmental changes and anthropogenic impacts (Sarker 1993; Nair 2004; Ahmed et al. 2008; Islam 2010).

At present, deltaic floodplains are intensively used for agriculture, industrial and fisheries production. They also play a significant role in developing the rural and urban socio-economic improvement in the region and patronized deltaic floodplain wetland ecosystems in the GBM Delta. The findings of this study could be used for a national deltaic resource management plan and protection of floodplains and its wetland ecosystems in the GangesBrahmaputra-Meghna River Delta in Bangladesh. Therefore, an integrated management plan is needed for protecting the deltaic floodplains and wetland ecosystems in the Ganges-Brahmaputra-Meghna Rivers Delta in Bangladesh.

\section{Objective of this study}

The objective of this study is to understand the characteristics and geological formation and development pattern of deltaic floodplains in the Ganges-Brahmaputra-Meghna Rivers Delta region between Bangladesh and India. There are some specific objectives of this study have been recognized as follows:

1. To understand the river systems and their role in delta development processes and characteristics in the river mouth of coastal regions.

2. To understand the wetlands ecosystem functions within the deltaic floodplain, their needed directions in management policies as well as future development strategies.

3. To investigate water salinity intrusion pattern in the lower tidally active coastal mangrove wetland regions and analysis of the degraded biodiversity and ecosystem in the deltaic floodplains.

4. Make recommendations for future development and management planning strategies for sustainability of wetland ecosystems and livelihoods in the Ganges-
Brahmaputra-Meghna Rivers Delta between Bangladesh and India.

\section{Geographical location, geological setting and physiographic characteristics}

Bangladesh is located in South Asia between $20^{\circ} 34^{\prime}$ and $26^{\circ} 38^{\prime}$ north latitude and $88^{\circ} 01^{\prime}$ to $92^{\circ} 42^{\prime}$ east longitude, with an area of $147,570 \mathrm{~km}^{2}$ (Sarker 2008). It has a population around 152 million (2010), with a low per capita Gross National Product (GNP) of US\$ 1390. The Gross Domestic Product (GDP) in Bangladesh expanded 6.12 percent in 2014. The country is bordered by India on the west, north and east sides. The other neighboring country is Myanmar, sharing the mountainous border $(288 \mathrm{~km})$ in the south-east (Fig. 1). The Bay of Bengal lies to the south of Bangladesh (Ahmed and Falk 2008). Three major landscape types are found in Bangladesh: floodplains (80\%), terraces (8\%), and hills $(12 \%)$ (Fig. 1). Except for the eastern hilly region, almost all of the country lies in the active delta of three major rivers like the Ganges, the Brahmaputra, and the Meghna. The location of the Ganges-Brahmaputra-Meghna Rivers (GBM) Delta is at latitude of $21^{\circ} 43^{\prime} 30^{\prime \prime} \mathrm{N}$ and $24^{\circ} 50^{\prime} 20^{\prime \prime} \mathrm{N}$ latitude. The longitudinal extension of the delta is from $87^{\circ} 49^{\prime} 17^{\prime \prime} \mathrm{E}$ to $91^{\circ} 21^{\prime} 00^{\prime \prime} \mathrm{E}$ longitude (Rob 1998; Woodroffe et al. 2006). The Ganges-Brahmaputra-Meghna (GBM) River Delta is located in South Asia within the GBM Rivers catchments areas between Bangladesh and India (Fig. 1).

The coastal zone of Bangladesh has dynamic geomorphologic features which are illustrated as a process of active delta development by the Ganges-BrahmaputraMeghna River systems. The major portion of the Bengal basin and the Ganges delta is floored with quaternary sediments eroded from the high lands on three sides and deposited by the Ganges, Brahmaputra and Meghna (GBM) Rivers and their tributaries and distributaries (Anwar 1988; Goodbred and Kuehl 2000). The physiography of Bangladesh is characterized by two distinctive features: a broad deltaic plain subject to frequent flooding, and a small hilly and terrace region crossed by swiftly flowing rivers. On the south it is a highly irregular deltaic coastline of about $710 \mathrm{~km}$, fissured by many rivers and streams flowing into the Bay of Bengal. The temperature varies from 23 to $40{ }^{\circ} \mathrm{C}$; annual precipitation range is 1474-2265 $\mathrm{mm}$. The dry months have an average rainfall between 20 and $65 \mathrm{~mm}$ and the average evapotranspiration rate is 15-90 mm/month (Anwar 1988; Goodbred and Kuehl 2000; Islam and Gnauck 2008).

The major ecosystems by distributaries levee, delta front (channel, distributary's mouth bar, distal bar, etc.) delta which are in turn modified by the effects of wave and wave 
influence processes, tidal processes, and to an extent semipermanent currents, oceanic currents and wind effects. The Bengal delta is extremely complex and dynamic because three different delta types exist here: tide dominated, tideriver dominated, and tide wave dominated (Anwar 1988).

\section{Data and methodology}

The present study was carried out based on primary and secondary data sources. The information of river systems in Bangladesh was collected from different governmental and non-governmental organizations, university libraries, and agencies. During the char-land studies on Padma River basin, some physical field observation and case studies were carried out on the Ganges and Brahmaputra (Jamuna) River characteristics. The physical observation on the rivers and river related conversation with local people especially in the south western region and the active deltaic region in Bangladesh. Data were also collected from the local people in the GBM Rivers catchment areas during field investigation and data collection period was in 2003 and a short field observation arranged in Bangladesh in 2008. The time series primary data (from 2000 to 2003) on water salinity and water quality on 13 rivers including Sibsa River, Passur River, Chunnar River, Kholpetua River, Bal Jhalia River, Baleswar River, Betmargang River, Notabaki River, Passakhali River, Arpongasia River, Kathka River, Nilkamal River, and Malancha River in the Sundarbans mangrove wetland regions were collected from Institute of Water Modelling (IWM), Dhaka with the permission of Asian Development Bank. Besides, some rivers including Munchiganj River, Mirgang River, Koira River, Kasiabad River, Mongla River, Kochikhali River, Bhairab River, Rupsha River, Haringhata River, Baisdia River and Meghna Estuary's water sample were collected personally and tested at Soil Resource Development Institute (SRDI) lab in Dhaka. Water quality related reports have been collected from IWM, Dhaka, BCAS (Bangladesh Centre for Advance Studies), Bangladesh Inland Water Development Board (BIWDB), Department of Environment and Forestry, Centre for Environment and Geographical Information Services (CEGIS) Dhaka. The Satellite imageries in digital and paper base issues from 1980 to 2010 were collected from SPARRSO, Ministry of Defense of Bangladesh. The satellite imageries on the Ganges-Brahmaputra-Meghna River Deltaic region such as MSS-5 TM 1980, LANDSAT-5 TM BRABD 2342002 and 2010 (colour) were used to investigate the changing behavior and development of deltaic floodplains.

The primary data on saline water was collected from mangrove wetlands. Freshwater data were was collected from a field survey and livelihoods information was collected from local people and stakeholders. Twenty-one focus group discussion (FGD) and participatory rural appraisal (PRA) practices were arranged with 390 people in the Sundarbans region in Greater Khulna district and Chanda-Bahgia beel wetlands areas in Madaripur and Gopalgonj districts. FGD and PRA were used for investigation of local participation and wetland management strategies in the deltaic floodplain regions. In addition, an in-depth investigation on water salinity modeling on 16 rivers in the Sundarbans region was carried out which gave the basic information and indigenous technical knowledge.

The secondary data were collected from the relevant published research works in the country and outside of the country. The published papers in journals and books in Bangladesh and outside of country were reviewed. The collected data were processed, analyzed, and visualized through MS Excel interpolation; VISIO 32, ArcGIS 9.3, 10.1 and MATLAB software. They were used for water salinity approximation to investigate the degraded deltaic floodplain wetland ecosystems in the Ganges-Brahmaputra-Meghna Delta in Bangladesh.

\section{The role of river systems in deltaic floodplains formation}

The major rivers play an important role in the formation processes of the Ganges-Brahmaputra-Meghna Rivers mega delta in South Asia (Goodbred and Kuehl 1999). In Bangladesh there are 257 large and medium rivers that have been recognized and they flow through the country and discharge into the Bay of Bengal, which have been recognized as a river and constantly altering their courses (Miah 2001; Schmuck 2001; Sarker et al. 2003). There are 59 transboundary rivers flowing from outside of Bangladesh territorial border (Miah 2001). The major rivers such as the Ganges-Padma, the Brahmaputra and the Meghna are carrying upstream water flows which join with the Bay of Bengal. Figure 2 shows the geo-historical development and changes of Ganges-Brahmaputra-Meghna Rivers system in Bengal from 1767 to 1991 . Figure 2 illustrates the Bengal river system in 1767 (Rennel's survey) and how the major rivers channels have gradually shifted, which have been shown in 1821 (by Wilcox survey) and in 1991 (ISPAN) (Schmuck 2001; EGIS 2000; Sarker et al. 2003). Based on the 1767 Rennel's map where the Brahmaputra was flowing along the present course of the Brahmaputra River at the east of the Madhupur Tract, that is also shifting of the main courses begun after 1976. In the Wilcox's map of 1830, it is also mentioned that the shifting process was accomplished by 1830 , it has further stated that huge accretion in the 1950s and 1960s caused the delta progradation and thus expedited the shifting process (Sarker et al. 2003, Sarker 2008, Sarker et al. 2011) (Fig. 2). 


\section{History of River Systems in Bangladesh (1767 - 1991)}

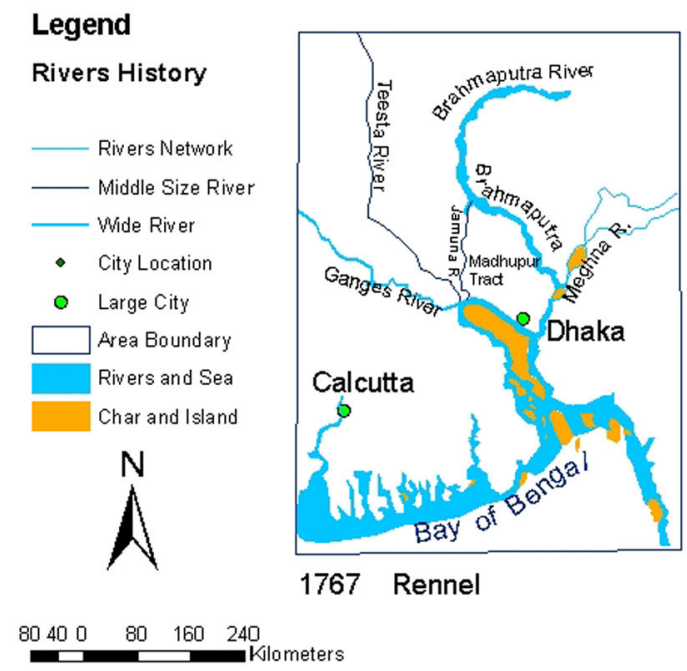

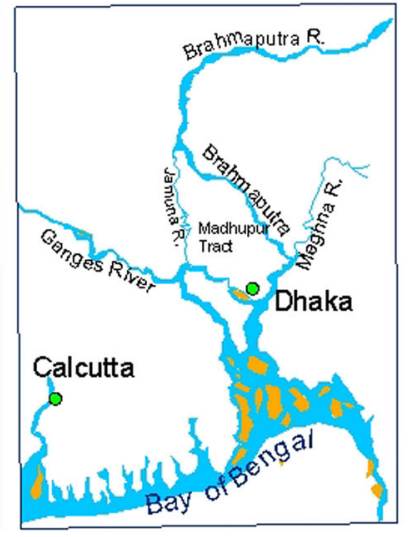

$1821-1834$ Wilcox

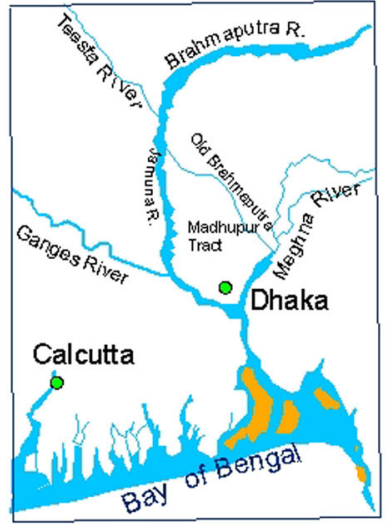

1991 ISPAN

Data Source: CEGIS, 2000

Fig. 2 River systems in the Ganges Deltaic floodplain regions (1767-1991) (Secondary Data Sources: Rennel 1793; Wilcox 1830; ISPAN 1995; EGIS 2000 and redrawing by Islam 2010)

The channel migration and sedimentation are also defining the shape and size of the Ganges-Brahmaputra-Meghna Delta. The river systems in the Bengal have historically influenced the deltaic floodplain and wetland ecosystems in the Ganges-Brahmaputra-Meghna Rivers Delta. There is a strong correlation between river systems and deltaic floodplain wetland ecosystems in the Bengal delta. The major rivers water flows show different scenarios in different months. Figure 3 illustrates the major rivers water flows in different months (January-December) in the GangesBrahmaputra-Meghna deltaic floodplains (Schmuck 2001; EGIS 2000; Sarker et al. 2003; CEGIS 2010).

The Ganges River receives over $60 \%$ of its discharge from its tributaries. The Gomti, Damodar, Yamuna Rivers, Mohananda are the major tributaries of Ganges Rivers in the Indian portion (Helmer and Hespanhol 1997). The main distributaries of the Ganges River in Bangladesh are the Baral, the Gorai, the Arial Khan, the Bhairab, the Mathabhanga, the Kumar, Chitra and the Ichamati River (Miah 2001). Their average annual combined discharge into the Bay of Bengal is 100,000-140,000 $\mathrm{m}^{3} / \mathrm{s}$ carried by Ganges-Brahmaputra-Meghna (GBM) Rivers (EGIS 2000). As a whole the Brahmaputra (Jamuna) River carries water flow $60,000-100,000 \mathrm{~m}^{3} / \mathrm{s}$. The minimum water flow of the Meghna River is $3750 \mathrm{~m}^{3} / \mathrm{s}$ (Figs. 2, 3).

The Ganges River is the major source of silt deposition and delta formation in the Bay of Bengal (Joseph 2006; Islam and Gnauck 2008). The Brahmaputra carries every year, about 600 million tons of sediments, with alluvial sand constituting large proportion (FAP 24 1996). The sediment is deposited as dunes in the river bed, which is about 350 , in some cases up to $600 \mathrm{~m}$ long and they can move very fast as $17 \mathrm{~m} / \mathrm{s}$ (FAP 24 1996; EGIS 1997). The Meghna delta is the main output of the Ganges, the Brahmaputra and the Meghna to the Bay of Bengal (Chowdhury and Haque 1990). The sediment load is extremely high, with suspended sediment load during flood stage reaching as high as 13 million tons per day (Coleman 1969). The strong south Asian monsoon and high Himalayan source area supports one of the world's largest riverine sediment loads (1.8-2.4 billion tons annually) for the Ganges-Brahmaputra-Meghna dispersal system (Anwar 1988; Umitsu 1993; Goodbred and Nicholls 2004).

Khan (1991) mentioned that the Ganges was probably the first river to develop and occurred during the Pleistocene period and flowed south along the present Bhagirathi-Hooghly River (West Bengal) to discharge into the Bay of Bengal. He also stated the Brahmaputra-Jamuna made little contribution to the building up of the delta. Niyogi (1975) stated that the Bhagirathi-Hoogly was the earliest course of the Ganges, to the followed by the GoraiMadhumati channel and finally the present day BhagirathiHoogly which was the main course of the Ganges nearly 600 years ago (Islam 2001). At present day Gorai-Madhumati flows through Haringhata River into the Bay of Bengal. It is suggested that most possibly likely the GoraiMadhumati was the original course of the Ganges which is not as active as today, but its size been reduced due to rapid siltation and river migration during the recent past (Khan 1991; Islam 2001; Goodbred and Kuehl 2000).

The combined flow and the sediment of GBM Rivers built the early Meghna delta and the present day Meghna delta (Chowdhury and Haque 1990). Throughout Pleistocene times, the site of active deltaic sedimentation has 


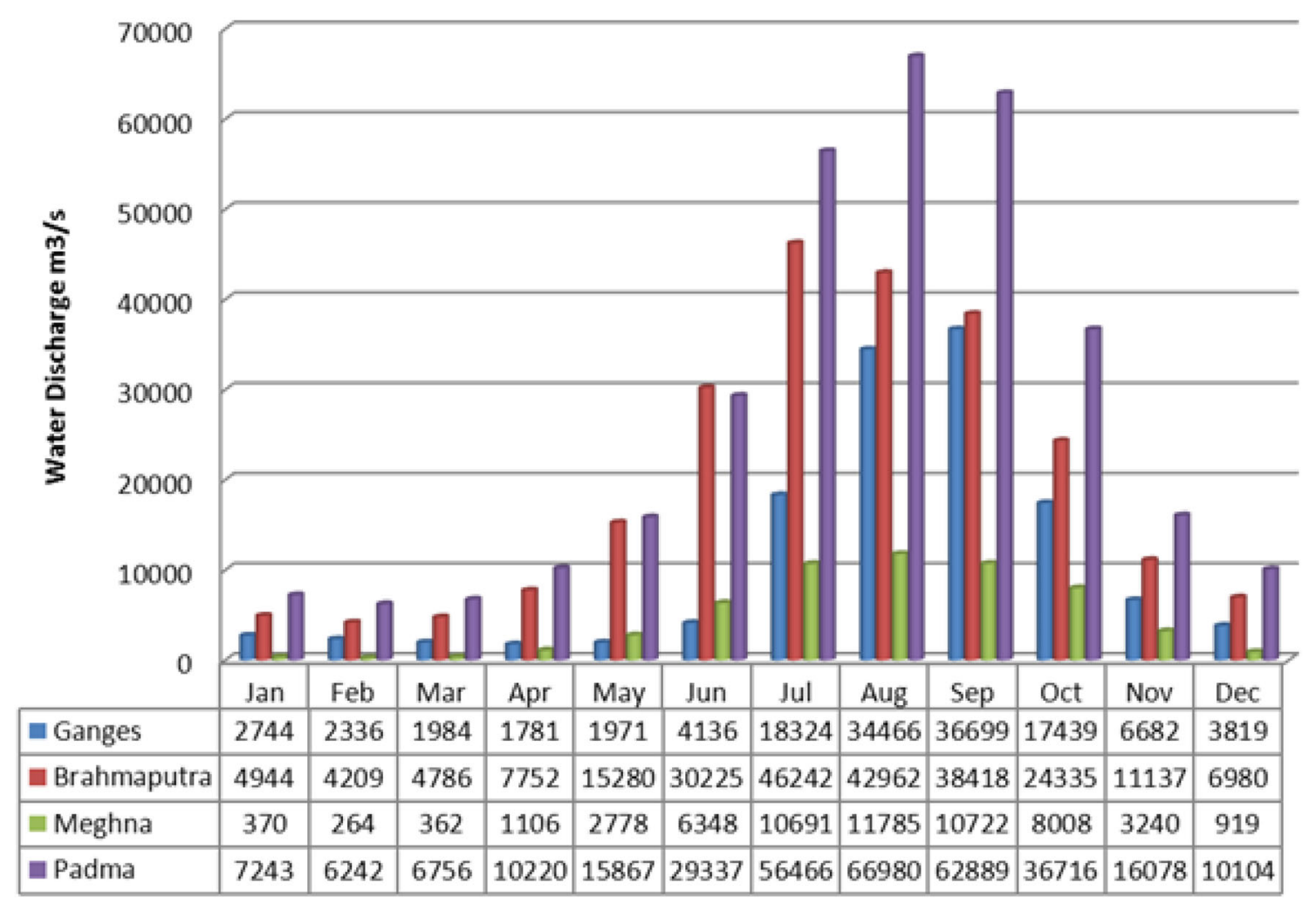

Fig. 3 Major rivers annual water discharge flow in the Ganges deltaic region (Data Source: Hunter 1894; EGIS 2000; Miah 2001; Goodbred and Nicholls 2004; CEGIS 2010)

switched. Today, the Ganges merges with the Brahmaputra, and the site of active sedimentation lies to the eastern side of the country of Bangladesh where large bell-shape distributaries are present. The theory behind this channel shifting is the violent earthquake of 1762 in the Indian province of Assam and the strong floods in the year 1787 and other plate tectonic movement (Coleman 1969; EGIS 1997; Schmuck 2001).

The Meghna estuary is now affected by high salinity intrusion. Constant sea salinity was imposed at the sea-end boundary in Meghna river delta. Characteristics, such as water salinity, basin shape, size and bathymetry energy regime, over basin behavior in terms of subsidence rates, tectonic activity, human interaction and interference and sea level fluctuation (Anwar 1988) of the receiving basin, influence the development of Bengal delta (Anwar 1988). The delta (Alluvial land) has come into existence by the depositional activities of the three mighty rivers of the region (EGIS 1997; Khan and Islam 2008; Islam and Gnauck 2008). The evolution in this delta region in Holocene period were carried out mainly by Fergusson (1863), Umitsu (1993), Goodbred and Kuehl (2000) and Allison and Kepple (2001). The late Quaternary geology and landsforms of the Ganges-Brahmaputra-Meghna Delta were done by Morgan and McLntire (1959) whereas sedimentary processes and landforms along the Brahmaputra (Jamuna) River were elaborately discussed by Coleman (1969). The late quaternary sediments and sedimentary environments of the GBM delta based on soil tests and grain size analysis in more than 300 columnar sections of bore holes in the Bengal delta and its surrounding region. The detailed delta development from the Quaternary through the Holocene was presented by Goodbred and Kuehl (2000) and Allison et al. (2003). Goodbred and Kuehl (2000) developed palaeo geographic maps of the Ganges-Brahmaputra-Meghna (GBM) Delta on Holocene period.

\section{The Ganges-Brahmaputra-Meghna Delta development}

The development of the Ganges-Brahmaputra-Meghna Delta began some 125 million years ago (Ma) after the fragmentation of the Gondwanaland. Since the early Cretaceous, it is still continuing to develop (Lindsay et al. 1991; Goodbred and Kuehl 1999). This is the largest delta and occupies the lower part of the Bengal basin of the South Asian region of Bengal (Islam and Gnauck 2008). 
According to the geological time scale, the delta came into existence by the depositional activities of three mighty rivers of the region. These are popularly called the Ganges (Padma), the Brahmaputra (Jamuna) and the Meghna River. The Brahmaputra delta formation started in the Miocene period (125,000 years ago) (EGIS 1997; Goodbred and Nicholls 2004) and the quaternary arcs shapes were developed approximately 50,000 years ago (Anwar 1988) which is recognized as the greater Mymensingh district (Fig. 4). The Ganges-Brahmaputra-Meghna Delta could be divided into two major divisions, according to the historical development of the delta in Bengal such as the early stage arcs (quaternary deltaic arcs) and the present day deltaic arcs (Anwar 1988, Allison 1998). The detailed explanation of quaternary deltaic arcs and the present day deltaic arcs are given in the following sections.

\section{Quaternary deltaic arcs in Bangladesh}

Three deltaic arcs were recognized in the early stage in Bangladesh. The deltaic region has developed its deltaic shape almost 50,000 years ago. The centre of Bengal basin occupied by trunk rivers (Ganges-Brahmaputra-Meghna) flowing along the basin axis as a longitudinal rivers. The basin axis seems to be unstable, and due to that the Ganges-Brahmaputra-Meghna Rivers have built up large deltaic arcs in recent times (50,000 years ago) which are (1) the early stage of Brahmaputra river delta; (2) the early stage of Ganges river delta and (3) the early stage of Meghna river delta (Fig. 4).

\section{The early stage of Brahmaputra river delta}

The deltaic region created or developed in the quaternary age and the present shape was developed almost 50,000 years ago (Islam 2001). The early position of the Brahmaputra river delta is located in the downstream of Brahmaputra River and the down of the Garo Hill. It is mostly located in the north-east side of Bangladesh. The greater Mymensingh district (Jamalpur, Sheerpur, Mymensingh, Netrokona and Kishorgonj districts) (Fig. 4) is formally called the early Brahmaputra delta. The coordinate of the early Brahmaputra delta is $24.43^{\circ} \mathrm{N}$ latitude to $90.78^{\circ} \mathrm{E}$ longitude. The estimated area of the early Brahmaputra River delta is approximately $13,258.24 \mathrm{~km}^{2}$ (Anwar 1988; Islam and Gnauck 2008).

\section{The early stage of Ganges river delta}

The early Ganges river delta developed about 50,000 years ago as the Brahmaputra river delta was formed at the same time. The early Ganges river delta is located in the west southern region in Bangladesh and a part of West Bengal of
India. The early Ganges delta is recognized the greater Kushtia and Jessore districts of Bangladesh (Kushtia, Chuadanga, Meherpur, Jessore, Narail, Magura and Jhenaidah districts) and North 24 Pargana, Nadia, and Murshidabad districts of West Bengal, India (Fig. 4). At present, the early Ganges delta is the part of moribund delta and mature delta of Ganges-Brahmaputra delta. The geographical coordinates of the early stage Ganges delta is $23.17^{\circ} \mathrm{N}$ latitude to $89.50^{\circ} \mathrm{E}$ longitude. The estimated area of the early Ganges delta is about $20,060.70 \mathrm{~km}^{2}$ (Anwar 1988; Islam and Gnauck 2008).

\section{The early stage of Meghna river delta}

The Meghna River originated from the Lushai hills in India and flows western by the name Barak. Entering to Bangladesh it bifurcates, then meets again and renamed as Meghna (Fig. 4). This river on its way down to the Sea receives the combined flow of the Ganges and the Brahmaputra and forms the biggest estuary in the Bay of Bengal. During its early stage, Meghna River delta was developed the same as other rivers in the Bengal in the quaternary age (Anwar 1988) (Fig. 4).

Earlier Meghna delta is the part of greater Noakhali and Bhola district (Noakhali, Lakshmipur, Bhola, Borguna, Patuakhali, Jhalokati, Barisal, Pirozpur and Chandpur districts). The geographical coordinates of the early stage Meghna River delta is $22.15^{\circ} \mathrm{N}$ latitude to $91.10^{\circ} \mathrm{E}$ longitude. The area of early Meghna delta is about $18,299.55 \mathrm{~km}^{2}$. The present day Meghna delta is actively pushing out the eastern side of the Bay of Bengal, whereas the early Meghna delta was formed by south southwest flow of Meghna river (Fig. 4) (Anwar 1988; Islam and Gnauck 2008).

\section{Present Ganges-Brahmaputra-Meghna Delta in Bangladesh}

At present, Ganges-Brahmaputra-Meghna Rivers Delta is popularly called as Ganges-Brahmaputra delta or Ganges delta or Brahmaputra delta or GB delta (Khan and Islam 2008). The development of the Ganges-BrahmaputraMeghna Delta began some 125 million years ago (Ma) and it is still continuing (Islam and Gnauck 2008). The area of the GBM Rivers Delta is $115,000 \mathrm{~km}^{2}$ (Schmuck 2001; Goodbred and Nicholls 2004; Woodroffe et al. 2006). The average elevation of the delta in Khulna Barisal, the southern part of Faridpur and the eastern part of Noakhali district is less than $2 \mathrm{~m}$ (Rob 1998; Islam 2006). The river courses in the delta are carrying water discharge of $29,692 \mathrm{~m}^{3} / \mathrm{s}$ in an average into the Bay of Bengal. The discharge is $100,000 \mathrm{~m}^{3} / \mathrm{s}$ during the flood time and $6041 \mathrm{~m}^{3} / \mathrm{s}$ during the low water season (Islam and Gnauck 


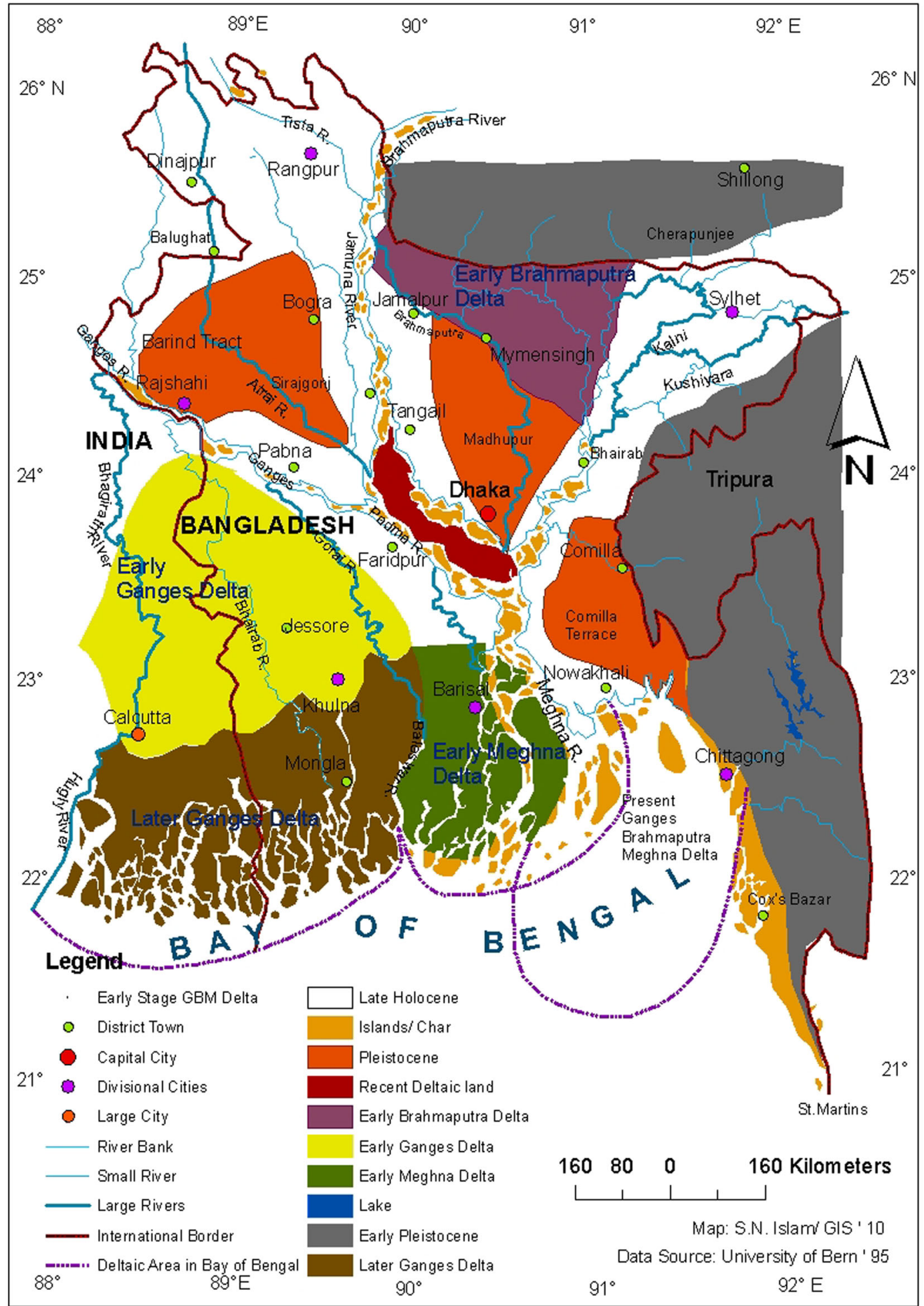

Fig. 4 Early stage deltas in GBM catchments (Data source: Hoper 1998)

2008). The present day Ganges Delta can be divided into four major categories as explained below (Fig. 5); (1) the moribund delta, (2) mature delta, (3) active delta and (4) tidally active delta.
The moribund delta

The western part of the deltaic floodplain border has demarked by the Gorai-Madhumati River. The area 


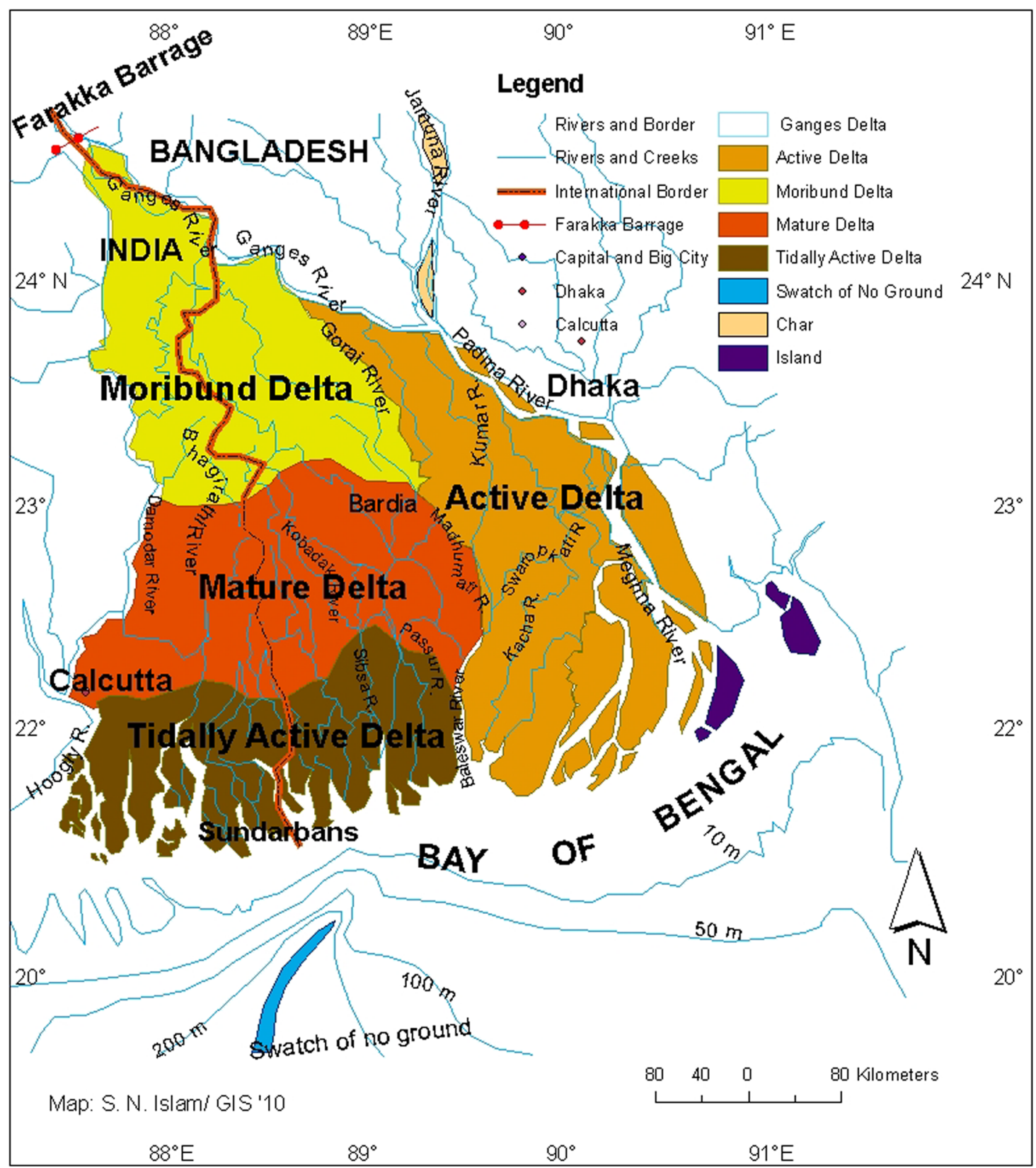

Fig. 5 Present day Ganges-Brahmaputra-Meghna Rivers Delta (Source: after Islam and Gnauck 2008)

comprises from northern Jessore and the greater Kushtia district (Mafizuddin and Ali 1993). The moribund delta lies between the latitudes of $22^{\circ} 10^{\prime} \mathrm{N}$ and $24^{\circ} 40^{\prime} \mathrm{N}$ and the longitudes of $88^{\circ} 0^{\prime} \mathrm{E}$ and $90^{\circ} 0^{\prime} \mathrm{E}$, it covers an area of $29,500 \mathrm{~km}^{2}$ in Bangladesh which includes Mushidabad (East portion of the Bhagirathi), part of Nadia district of India and Meherpur, Chuadanga, Kushtia and the northern part of greater Jessore district of Bangladesh (Fig. 5) (Goodbred and Kuehl 1999; Islam 2006; Islam and Gnauck 2008). The deltaic area lacks the important effect of the flooding from the Ganges and is characterized by rivers that are now abandoned or drying up. Due to drastic fall in the flow of the Gorai River, at least seven of the 15 rivers dependent on it are now nearly dead while eight others are following. The nearly dead rivers are Hisna, Kaliganga, Kumar, Kamkumra, Harihar and Chitra. These rivers have lost their connections with their parent streams (Fig. 5).

The rivers receive no off-take from the main stream which does not bring down enough water and silt, even in flood, and being confirmed within high levees, are not in a position to inundate the entire area (Brammer 1996). As a result, land build-up has happened and the delta has grown moribund up to this limit (Fig. 5) (Islam 1995). 


\section{The mature delta}

The mature delta comprises the saline, non-forested areas in the northern part of the Khulna (Islam 1995). The mature delta lies between the latitudes of $23^{\circ} 16^{\prime} \mathrm{N}$ to $20^{\circ} 10^{\prime} \mathrm{N}$ and longitudes of $87^{\circ} 50^{\prime} \mathrm{E}$ to $89^{\circ} 70^{\prime} \mathrm{E}$. The mature delta covers an area of approximately $28,500 \mathrm{~km}^{2}$ in Bangladesh and West Bengal of India (Fig. 5). It includes Murshidabad, Nadia and 24-Pargana of India and Meherpur, Kushtia, Chuadanga, Jhenaidah, Magura, Jessore, Norail, and northern part of Khulna, Sathkhira and Bagerhat districts of Bangladesh (Islam 2006; Islam and Gnauck 2008). In the mature delta, the land is suitable for cultivation but salinity intrusion is a major threat for agricultural cultivation and terrestrial ecosystems in summer (March-May) at the greater Khulna and Jessore districts (Fig. 5). The urbanization growth is very high in the Ganges mature delta. The highly populated major cities such as Calcutta, Khulna, Bagerhat and Satkhira are located in the mature delta (Fig. 5). Due to high salinity in the mature delta the agricultural cropping intensity is very low in this area (Islam 1995).

\section{The active delta}

The Ganges-Brahmaputra Rivers' active delta lies between the latitudes of $23^{\circ} 70^{\prime} \mathrm{N}$ and $21^{\circ} 55^{\prime} \mathrm{N}$ and the longitudes of $89^{\circ} 10^{\prime} \mathrm{E}$ and $90^{\circ} 50^{\prime} \mathrm{E}$ and covers an area of about $26,500 \mathrm{~km}^{2}$. The area is about $300 \mathrm{~km}$ long in the northsouth direction and almost 100 and $130 \mathrm{~km}$ wide in the upper and middle reaches of the active delta respectively (Fig. 5). The active Ganges-Brahmaputra delta includes Rajbari, Faridpur, Madaripur, Shariatpur, Gopalgonj, Pirojpur, Jhalokhati, Barisal, Borguna, Patuakhali, Bhola and Lakshmipur districts of Bangladesh (Islam and Gnauck 2008). The area about $26,500 \mathrm{~km}^{2}$ is considered for deltaic lands excellent (Fig. 5) (Islam 1995; Goodbred and Kuehl 1999; Islam 2006). The non-saline tidal and estuarine charlands and islands constitute a sort of transitional region to the saline delta. However, in the southern part of the Barisal and Patuakhali districts salinity is also a handicap and precludes cultivation of crops other than paddy during the rainy season (Islam 1995).

\section{The tidally active delta}

The most south-western part of the Ganges delta is a coastal mangrove area and tidally active delta (Islam and Gnauck 2008). The present tidally active delta lies between the latitude of $22^{\circ} 10^{\prime} \mathrm{N}$ to $20^{\circ} 90^{\prime} \mathrm{N}$ and the longitude of $87^{\circ} 50^{\prime} \mathrm{E}$ to $89^{\circ} 60^{\prime} \mathrm{E}$. It is dominated by coastal tidal waves and currents. The actual tidally active delta is the territorial part of southern part of Sundarbans region. The area is approximately $20,000 \mathrm{~km}^{2}$ wide and includes the south western part of the coastal region especially the major portion of Bagerhat, Khulna, Sathkhira district of Bangladesh and South 24-Pargana district of West Bengal of India (Fig. 5) (Islam 2006; Islam and Gnauck 2008). The northern limit of the present day Sundarbans was established at ca. 3000 years BP. The coast line retreated from the Khulna region is about 1800 years BP. The northern limit of this last transgression is unknown (Gupta 1981; Islam 2001). According to Khan and Islam (2008) the lower deltaic coastal floodplain has fives assemblages which are recognized in the lower coastal deltaic plain in five different depositional environments such as: (a) levee or levee complex, (b) Beel or depression, (c) abandoned meander belt, (d) interdistributary and (e) estuarine plain (Khan and Islam 2008).

The thickness of the Holocene sediments ranges from 30 to $70 \mathrm{~m}$ in the deltaic plain, usually floored by the Pleistocene period stiff clays with the exception of the abandoned meander belt deposit, where Holocene channel sand deposited directly on the Pleistocene sand (Khan and Islam 2008). Beside this the coastal subsidence ( $3 \mathrm{~mm} / \mathrm{a}$ on average) occur in the coastal region in Bangladesh, which is in general the tidally active and the southern part of lower active delta (Goodbred and Kuehl 2000; Khan and Islam 2008). A predicted rise of relative sea level movements will deteriorate the sustainability of the present mangroves vegetation of Bangladesh (Islam 2001; Milliman et al. 1989). The study would therefore suggest that most of mangroves along the Bangladesh coast and the tidally active delta would collapse under sea level scenarios, rate of rise up to $1.5 \mathrm{~cm} /$ year have been predicted by IPCC (2007).

According to the formation and development of delta, the Ganges-Brahmaputra-Meghna Delta can be divided into three major categories, which are such as (1) development stages, (2) quaternary deltaic arcs and (3) recent GangesBrahmaputra-Meghna Delta. Each category has divided into sub-categories. All the major categories and sub-categories have been discussed in more detail in general discussion sub chapter. The present management and conservation of the wetlands in the Ganges-Brahmaputra-Meghna Delta is in an alarming condition. There is no proper management plan or policies existing for the protection of sensitive wetlands in the Ganges deltaic floodplain region in Bangladesh.

\section{Wetlands ecosystem management in the deltaic floodplains}

The Bengal basin is one of the largest geosynclines in the world. It is formed by sub ducting of the north-east part of Indian plate, which started in the early cretaceous (Benerji 1981; Islam 2001). The alluvial and deltaic sediments of the Ganges-Brahmaputra-Meghna Rivers build the Bengal 
delta (Morgan and McLntire 1959). The Bengal basin was dissected in unfilled many times by the major rivers during Pleistocene times leading up to the last glacial maximum at $18,000 \mathrm{BP}$ when the sea level stood some $130 \mathrm{~m}$ lower than present (Umitsu 1993; Kudrass et al. 1999; Goodbred and Kuehl 2000). The aquifer sands are shown in fine quality at medium grained with typical hydraulic conductivities of $10-50 \mathrm{~m} /$ day, which contain water that is less reducing, low in $\mathrm{Fe}$ and $\mathrm{AS}$ and it is generally less mineralized (Ravenscroft 2003). It is estimated that some 1.8-2.4 billion tons of sediment is suspended into the Bay of Bengal yearly (Anwar 1988; Nishat 1988).

Curray and Moore (1974) show an enormous sub aqueous delta beneath the Bay of Bengal formed by the sediment derived from the Ganges-Brahmaputra-Meghna Rivers. The shoreline changes of the Bengal delta during different geological time scales. Islam (2001) studied on coastline changes, which have been reconstructed along the Bengal delta for the period since the early mid-Holocene. The shoreline was moving uniformly in a south-east direction. Significant changes in floodplain formation take place during the later part of the mid-Holocene. Delta building was faster (up to $41.17 \mathrm{~m} / \mathrm{year}$ ) in Khulna, Pirozpur and the surrounding region than in the Calcutta, Satkhira, Jessore and surrounding regions (Islam 2001). It has been estimated that the Bengal coastlines have been moving in a south eastern direction since the early midHolocene (Islam 2001). The whole zone is geohydrologically a dynamic one undergoing morphological change in recent centuries (Elahi et al. 1998). The deltaic coastal geomorphology of Bangladesh characterized its funnel shaped, vast network of rivers, strong tidal and wind action as well as an enormous river discharge laden with bed, and suspended sediments (Islam 2001).

The ecosystem, according to Allee and Collaborators, may be defined as the interacting environmental and biotic system (Allee et al. 1949). Eugene Odum characterizes that the ecosystem as a natural unit which is exchanging of naturals between the living and nonliving parts follows circular paths (Eugene 1953). An ecosystem is a dynamic complex of plant, animal, and microorganism communities and the nonliving environment interacting as a functional unit. Humans are an integral part of ecosystems. Ecosystems vary enormously in size; a temporary pond in a tree hollow and an ocean basin can both be ecosystems.

The sophisticated definition of ecosystem can be structured on the following formulas.

The meanings of the ecosystem mean the functions of biotic and abiotic characters like as:

Ecosystem $=f($ biotic and abiotic characteristics $)$

$=f(\mathrm{~S}, \mathrm{cl}, \mathrm{pm}, \mathrm{o}, \mathrm{mo}, \mathrm{r}, \mathrm{w}, \mathrm{e}, \mathrm{t}, \ldots)$ where $\mathrm{S}$-soil, cl-climate, pm-parent material, o-organism, r-relief of topography, w-water, e-energy, $\mathrm{t}$ time, etc.

The above Eqs. (1) and (2) are representing the mathematical formula and equations of the scientific meaning of ecosystem.

The evolution of the Ganges-Brahmaputra-Meghna Rivers Delta (GBMRD) ecosystem contains six spheres in the floodplain, such as (1) the natural and fluvial environment, (2) wetlands environment, (3) coastal aquatic and mangrove environment, (4) the agricultural and settlement environment, (5) the culture and heritage environment, and (6) socio-economic environment (Costanza et al. 1992; Daily et al. 1997; MEA 2005a, b). In addition, the progression of deltaic floodplain ecosystem of the GBMRD has been valued in different categories; for example in ecological values, economic values, social values, culture and heritage values. Furthermore, based on the definition, the deltaic floodplain ecosystem services are classified into four categories and offer deltaic ecosystem goods and services (Costanza et al. 1992; Daily et al. 1997; MEA 2005a, b).

The 'ecosystem services' is the benefits of human welfare which obtained directly or indirectly from ecosystems. So the deltaic floodplain ecosystem services are associated with a range of benefits for human lives and livelihoods. The Millennium Ecosystem Assessment (MEA) summaries these as being associated with supporting, regulating, provisioning and cultural roles (MEA 2005a, b). According MEA description, (1) Provisioning services includes food and water, genetic resources, cultivated land basin, mineral resources, nutrient cycle and biomass energy; (2) Regulating services includes regulation of climate, floods, drought, land degradation, social violence regulation and disease, erosion control and improve filtration of groundwater stabilization; (3) Supporting services includes ecological function, soil formation and nutrient cycling, floodplain agriculture, pollination of crops, maintenance of genetic diversity and biophysical support to other systems; and (4) Cultural services includes recreational, spiritual, religious, socio-cultural events, aesthetic values and other nonmaterial benefits (Costanza et al. 1992; Daily et al. 1997; MEA 2005a, b).

The sediments transported by the rivers primarily consist of fine sands silts and clays. The nature of sediments and great amount of material imposed on the channels by watershed causes, the rivers constantly adjust their bed configurations to differing flow regime. The largest delta has existed since early Tertiary stage (50 million years ago) (Anwar 1988). The geological history of Bangladesh has been greatly influenced by four stages of sea-floor spreading, two of which are still active. The sediments were transported and deposited by mighty rivers in the north Sylhet basin (Surma) and Bengal basin (Faridpur), 
where a deltaic environment prevailed most of the time, but it was occasionally interrupted by marine, near shore, tidal and fluvial environments (Anwar 1988). The GangesBrahmaputra-Meghna Rivers, carrying sediments and particles, were delivered at the beginning of the glacier period and due to the heavy rainfall, the subarial part of the Ganges-Brahmaputra-Meghna Delta started to form around 9500 BP (Goodbred and Kuehl 2000).

The delta formation was retained considerably around $7000 \mathrm{BP}$, when the Brahmaputra, a major contributor to the delta started to carry sediments into the Sylhet basin, an inland basin, when seriously starved the delta to maintain the coastline of the Bay of Bengal (Goodbred and Kuehl 2000; Khan and Islam 2008). The Brahmaputra shifted back to the bay again around $5500 \mathrm{BP}$ and the present delta configuration appears to have developed by $3000 \mathrm{BP}$ (Goodbred and Kuehl 2000).

There are thousand wetland sites, which are located in the Ganges-Brahmaputra-Meghna Delta between Bangladesh and in West Bengal of India. Only the major wetlands are recognized as ecologically sensitive sites. Few sites are declared as Ramsar Wetland sites and UNESCO World
Heritage sites like the Sundarbans mangrove wetlands (1997 in Bangladesh and 1987 in India). The wetlands include rivers, estuaries, mangrove swamps, marsh (haor), oxbow lake (baor) and depressed land (beels), water storage reservoirs, fish ponds, and some other lands, which suffer from seasonal inundation (Khan 1993; Hughes et al. 1994; Gopal and Wetzel 1995; Islam 2010).

The wetlands have been designated as ecologically sensitive sites in the Ganges delta in Bangladesh. The location of the wetland areas are as follows; (1) Marjiat baor (fresh water oxbow lake) (320 ha), (2) Atadanga haor (marsh area) (1002 ha), (3) Chanda-Bahgia beel (depressed area) $(16,600 \mathrm{ha})$ with $125 \mathrm{Mt}$ of peat, (4) SowagramGopalpur beel (7200 ha), (5) Beel Dakatia (26,600 ha), (6) Arial beel (14,400 ha), (7) Mathbaria beel (199 ha), (8) Khalia beel (136 ha), (9) Ghagail beel (130 ha), (10) Naldanga beel (210 ha), (11) Bayargeri beel (310 ha), (12) Tarail beel (430 ha), (14) Sundarban west (71,402 ha), (15) Sundarban south $(36,790 \mathrm{ha})$, and (16) Sundarban east (31,227 ha) (Fig. 6).

There are some ecologically sensitive sites, which are located within the deltaic floodplain territories like Char

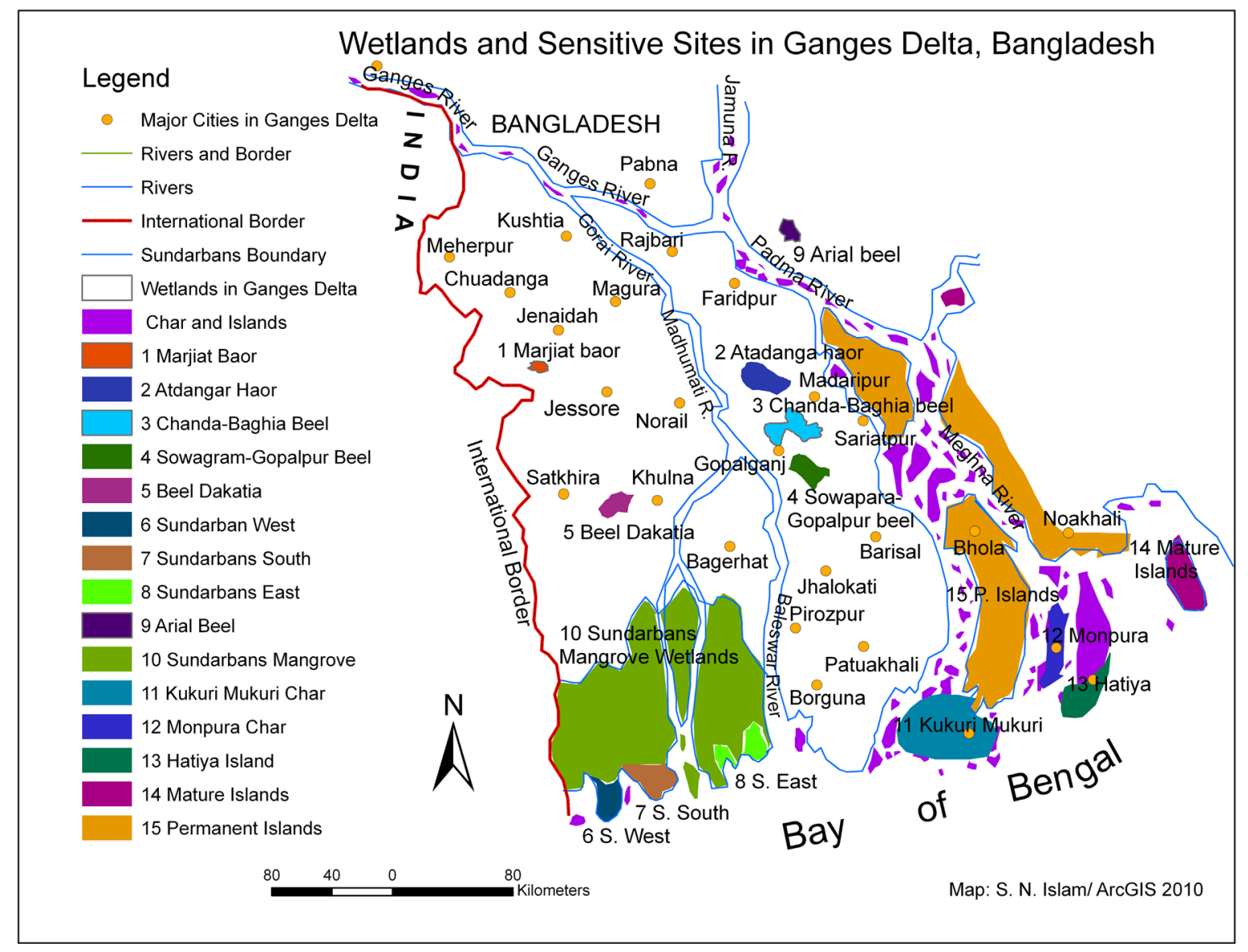

Fig. 6 Major wetland distributions in the Ganges-Brahmaputra-Meghna Delta in Bangladesh part (Data Source: EGIS 2000; Hoque and Alam 1995; Islam 2010) 
Fig. 7 Wetland ecosystem functions and socio economic benefits (Source: after Islam 2010)

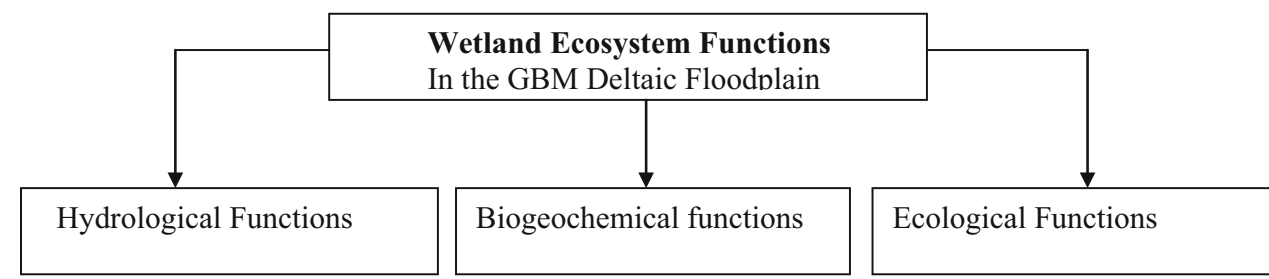

Flood water retention Surface and ground water recharge

Nutrient retention \& export Salinity retention in water and soil

Nursery and habitat Nursing plants, animals and microorganisms, biodiversity, landscapes and structural diversity

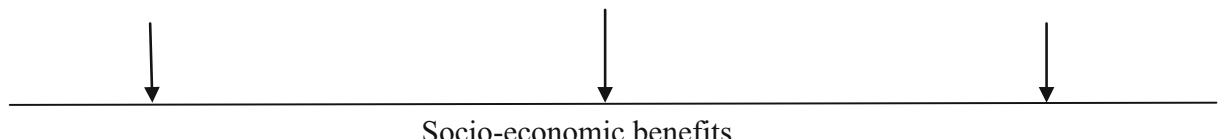

Socio-economic benefits

Alternative flood protection Flood water storage reduce, damage to property and resources Supporting food chains

Water supply Transport of sediment Delicate balance
Improve water quality Medicinal plants \& genetic
Waste disposal
Industrial and irrigation
Industrial and succession
Purification and cleaning up
Fish breeding
Ecosystems maintenance
Toxicant retention
Fishing and grazing
Shrimp culture
Crops fodder and fuel
Settlements places
Cultural and tradition
Aesthetic values
Spiritual, heritage values
Eco-tourism \& recreation
Employment of the poor

Kukuri Mukuri, Monpura Char, Hatiya Island, Sonadia Island, Meghna estuary and the Balesawar estuary. The major peat deposits occur in the Ganges-Brahmaputra delta and a limited peat deposits in the Sylhet basins in northeast (Akonda 1989; Islam 2001; Goodbred and Nicholls 2004). The Ganges deposits are underlain by a shallow layer $(0.08-1.50 \mathrm{~m})$ of alluvial silt. In general, the peat occurs mainly in the southwest region, which has reserved of $33 \mathrm{Mt}$ (dry weight). The main peat deposits occur in the Khulna district (Kola mouza; $39 \mathrm{~km}^{2}, 8 \mathrm{Mt}$ ). The present peat land is distributed in the following divisions, i.e. about $20 \%$ peat land reserved as virgin (untouched), $60 \%$ used for agriculture and horticulture, and $20 \%$ used for pisciculture (Akonda 1989; Nishat 1988). In general the local and indigenous communities are directly dependent on the wetlands resources in the Ganges-Brahmaputra-Meghna Deltaic floodplain. Figure 6 shows the freshwater, mangrove and coastal saline wetlands in the Ganges delta. There are 20 most important wetlands are located and 16 out of 20 wetlands (Fig. 6) are under threat due to climate change impacts and anthropogenic influences on natural resources. Water and soil quality has degraded because of high chemical pollution and salinity intrusion in the coastal region (Islam 2010; Islam et al. 2014a, b).
Wetland plays an important role in different ecological functions. Figure 7 illustrates the wetland functions and socio-economic benefits in the surrounding communities. The three major functions are hydrological, biogeochemical and ecological functions. These three functions are providing socio-economic benefits to the local communities and stakeholders around the wetlands (Fig. 7).

The wetlands of the Ganges-Brahmaputra-Meghna Rivers Delta regions are divers, and each has some special distinctive features in terms of physiography, seasonality, and use patterns (Rahman 1988). Wetlands of the GangesBrahmaputra-Meghna Rivers Delta region are one of the major sources of livelihoods particularly for cultivating food crops, vegetables, fishing, and pasture lands (Khan et al. 1994). Additionally they provide food and nonfood aquatic resources and retain the ecological balance for the local residents as well as for the nation.

\section{An approach for delta management and wetland ecosystem sustainability}

Deltas account for $\sim 1 \%$ of global land area, but are home to over 500 million people. They play a key role in agricultural production and commerce-yet, deltas are amongst 
the world's most threatened socio-ecological systems, a situation projected to amplify in the twenty-first century due to natural and anthropogenic impacts. The present study findings illustrate that the wetlands natural resource management is not a satisfiable. Presently there is no proper management plan for the saline and fresh water wetlands in the Ganges deltaic floodplains. The delta formation, management and resource sustainability is a dynamic subject for the deltaic floodplain sustainability. The following structural and non-structural aspects should be considered urgently for the sustainability of the Ganges-Brahmaputra-Meghna Rivers Mega Delta floodplains morphology and the wetlands ecosystems protection within the deltaic floodplains between Bangladesh and India. The delta management could be an integrated productive stable landscapes and land use approach. The management approach should be considered within the delta management guideline and framework for long term and short term concern, hydro-engineering aspect and geopolitical issues should be taken into high priority. Considering the results of this study the new barrages on the Ganges and Padma river in Bangladesh, and analysis the environmental changes in India and Bangladesh's geopolitical relationship that could make such development feasible (Colombi and Bradnock 2003). The delta management approach should also consider two basic concept of management. The first the following important aspects should be included in delta formation, morphological stability and ecosystems development concerns. The second aspect should be the deltaic wetlands ecosystems, ecosystem services and integrated management aspects. The following important aspects should be incorporated within the integrated deltaic floodplains formation and development, and wetland ecosystems management in the Ganges-Brahmaputra-Meghna Rivers Deltaic floodplains between Bangladesh and India. The following aspects are the most important subjects that should be considered as a high priority basis and these should be urgently implemented in the Ganges deltaic floodplain regions between Bangladesh and India such as:

- Delta related data bank development and monitoring system modernized.

- Control the channel migration process within a hydraulic engineering structure and mechanism.

- Capacity building for river training and river regulate within the deltaic floodplain areas.

- River bank protection or river bank training structure development should be a regular monitoring and management programme of the Authority of the Department of Rivers and Water Resources in Bangladesh.

- Sediments management and water flows control in the Ganges-Brahmaputra-Meghna Rivers basins.
- Capital dredging in the deltaic floodplain is essential (presently the Mongla-Ghashiakhali River is under capital dredging process) which is a minor action in consideration for such huge delta management.

- Maintenance dredging and regulate all waterways in the Ganges-Brahmaputra-Meghna Rivers deltaic catchment area.

- Land use sustainability should be ensuring as the charland and river bank area is not stable in the GangesBrahmaputra-Meghna Rivers Deltaic floodplain regions.

- Salinity intrusion in the deltaic coastal region is a high threat for land use agricultural sustainability and protection of wetland ecosystem that should be controlled within a scientific approach and mechanism.

- Ground water stabilization is one of the important hydraulic disputes in the deltaic floodplains region, as $80 \%$ ground water is using for household and irrigation purposes in the Ganges-Brahmaputra-Meghna Rivers Deltaic region.

- Flood monitoring, mitigation and management of flood impacts are very essential in the deltaic floodplain regions.

- Existing embankment and polder system are not in a regulating structure which is the reasons for coastal ecological damages due to salt water stagnant and unregulated polders in the Ganges-BrahmaputraMeghna River Deltaic coastal region in Bangladesh.

- The tidal cycle in the coastal region of the Ganges Delta should eco-friendly.

- Control the soil fertility, land use and landscapes and ensure deltaic floodplain biodiversity conservation.

- Plantation in the river bank area and the coastal regions towards protect deltaic morphology.

The fresh and saline water wetland ecosystems are under threat, because of water quality degradation. It has been investigated that the local community around the wetlands are dependent on wetland natural resources. The natural resources are being destroyed on a higher scale. The wetlands sites of the southern coastal region are negatively affected by saline water intrusion. The anthropogenic influences on the wetlands resources in 15 recognized sites, which has been already marked with a red list. Figure 8 shows as a policy approach model of wetland resource management in Bangladesh. For the better planning and sustainable management of wetland resources the fundamental modeling structure, its prime factors and sub factors should be followed properly (Islam et al. 2014a, b).

The conceptual model (Fig. 8) implementation in fresh and saline water wetland sites in Bangladesh could achieve good results for a better management and conservation, which further more could ensure livelihood sustainability 
could break the long-jam of a zero-sun game approach to surface water development in the Ganges-BrahmaputraMeghna Rivers Delta. The large scale dam-buildings and construction on the river channels and in the coastal polders are created population displacement in the earlier Ganges-Brahmaputra-Meghna Rivers Delta schemes. The present findings and the proposal could bring hydro-engineering, economic, environmental and political advantages to all users and beneficiaries in the Ganges-BrahmaputraMeghna Rivers Deltaic region in Bangladesh and the West Bengal of India.

\section{Discussion}

According to the geological time scale, the rivers of Bangladesh are playing a role in developing and forming the deltaic floodplains in Bengal. The early stage GangesBrahmaputra-Meghna Rivers deltas and the present Ganges-Brahmaputra-Meghna Rivers Delta developed in different geological time scales within the Ganges catchments in the downstream territories in Bengal. The Ganges-Brahmaputra-Meghna Rivers are recognized as highly predictable river system for agricultural production, socio-economic and industrial development, simultaneously for protection of floodplain and wetland ecosystems. These three rivers carry $100,000-140,000 \mathrm{~m}^{3} / \mathrm{s}$ upstream water and almost 1.8-2.4 billion tons of sediment loads, which deposits on the beds of the rivers and thrown in the Bay of Bengal (Anwar 1988; Nishat 1988). Recently, the river courses in the delta are carrying water discharge $80,684 \mathrm{~m}^{3} / \mathrm{s}$ during the flood time and only $6041 \mathrm{~m}^{3} / \mathrm{s}$ during the low water dry season. The Gorai River is one of the main distributaries of the Ganges River and carrying fresh water in the south western deltaic floodplain in Bangladesh, as well as in the Sundarbans mangrove wetlands area. Consequently, the ecosystems of the Ganges floodplains and mangrove wetlands are dependent on the availability of upstream fresh water supply in the coast by the Ganges-Brahmaputra-Meghna River system (Hoque and Alam 1995).

The 13 major rivers have been selected for water salinity investigation in the Sundarbans mangrove wetland region. The salinity intrusion in the river's water shows the high rate of salinity concentration which threatens deltaic floodplains and its wetland ecosystems (Begum 1987; Islam and Gnauck 2008). The southwestern coastal region such as the tidally active delta and active deltaic region are receiving low quantity of water after the construction of the Farakka Barrage on the Ganges River in India due to water withdrawal fresh water for irrigation and other purposes in the lean season. The Ganges flow was $3700 \mathrm{~m}^{3} / \mathrm{s}$ in 1962 , but it has reduced to $364 \mathrm{~m}^{3} / \mathrm{s}$ in 2006 (Nishat 2006). The reduction of Ganges fresh water in the upstream area is the root cause of salinity intrusion in the southwestern region of Bangladesh. As a result, the high saline sea water has penetrated in the upstream, and falling water tables occurred in the Ganges deltaic wetlands region. Therefore, the intrusion of salinity and alkalinity has degraded vegetation, agricultural cropping systems and changing the cultural landscapes in the GBM floodplains of Bangladesh (Islam and Gnauck 2008; Islam 2010). The impact on soil compaction starts with the destruction of surface organic matter and soil fertility for vegetation production and mangrove species germination in tidally active deltaic regions (Islam and Gnauck 2008). The changes altered basic soil characteristics related to aeration, temperature, moisture and the organisms that live in the soil. The core elements of the ecosystem such as soil, water, parent materials, climate, organism, vegetation and wildlife are strongly affected by saline water penetration process, which has degraded soil fertility. In the southwestern region almost $60 \%$ of surface water quality has been degraded and it has recognized as poor quality for drinking (EGIS 2000).

It has been indicated that there is a strong relation with Ganges water supply and salinity intrusion in the deltaic wetland regions. If Ganges River carries $500 \mathrm{~m}^{3} / \mathrm{s}$ fresh water in the dry season then the salinity threshold line would not be crossed. To protect the mangrove wetland ecosystems, the minimum requirement of Ganges fresh water is $500 \mathrm{~m}^{3} / \mathrm{s}$ and it is unremittingly needed at Hardinge Bridge point of the Ganges River in Bangladesh. The study findings show that about $75 \%$ land area of Satkhira district, $66 \%$ land area of Bagerhat district and $32 \%$ land area of Khulna district are sloppily affected by water and soil salinity. The lowest salinity rate is less than $10,850 \mathrm{dS} /$ $\mathrm{m}$ and the highest rate is over $43,220 \mathrm{dS} / \mathrm{m}$, the recommended water salinity value is $2161 \mathrm{dS} / \mathrm{m}$ for potable drinking water and some sensitive agricultural crops production (Islam and Gnauck 2009b). In the coastal area almost $17,000 \mathrm{~km}^{2}(20.4 \%)$ of new floodplain land area has been affected by various degrees and $38 \%$ of the countries floodplain territory and $33 \%$ of their population is already affected by salinity intrusion (SRDI 2000; Islam 2006). The rice production in the southwestern region of the Ganges delta has been extremely reduced: the output of rice production in 1976 was 236,000 metric tons, whereas the present production rate has been decreased to three times in 2008 (Islam and Gnauck 2008). Many number of mangrove species became extinct during the last 40 years in the Sundarbans mangrove wetland region. The dominated mangrove species Sundari (Heritiera fomes) and Goran (Cariops decandra) are affected by top-dying disease. Almost $310 \mathrm{~km}^{2}$ areas of Heritiera fomes type of forest are moderately and $275 \mathrm{~km}^{2}$ are severely affected, 
which is one of the main threats for a sustainable mangrove management and protection of its wetland ecosystems.

The flow of the Ganges river at the Hardinge Bridge point is 1.4 times higher than the Farakka point in India (Miah 2001). As a result of continuing decreases of fresh water in the Ganges basin at the Hardinge Bridge point the downstream is facing water scarcity, which is a threat for quality drinking water, irrigation, ecosystem, mangrove ecosystem services and livelihoods in the coastal region of the Ganges floodplains. The recent deltaic coastal floodplains and wetlands are getting more vulnerable due to high salinity intrusion through tidal waves and upstream fresh water reduction from the Ganges basin. Over 1.65 million hectares of salt affect floodplains in southern and southwestern part, $3400 \mathrm{~km}^{2}$ of lower active deltaic coastal wetlands are affected by slight to slight salinity (Ahsan 2001; Ahsan and Rahman 2001).

The quality of water in the Sundarbans mangrove wetland and surrounding area is getting low owing to high concentration of $\mathrm{NaCl}$ in water. The other parameters of water quality have not been considered in my research. The $\mathrm{pH}$ value of river water in the active deltaic floodplain area was found to be 7.5 ; the river water was a little alkine (Islam and Gnauck 2008). The organic matter in southwestern region of the Ganges floodplain and wetlands areas were found $0.88-1.34 \%$ which was very low comparing to other places in the coastal region. As a whole, the elements of ecosystems are being affected through salinity intrusion inside and outside of the Sundarbans mangroves and in the floodplain wetlands in the delta (Islam and Gnauck 2007, 2008). The continuous penetration of salinity is the cause of loss of coastal and mangrove biodiversity, degrading the quality of water and soil of the entire deltaic floodplain wetland areas (Islam and Gnauck 2008, 2009a).

The Ganges deltaic floodplain region including the Sundarbans mangrove and freshwater wetland ecosystems are bound to respond to the various ecological threats, such as landscapes changes, land degradation, salinity intrusion, erosion, siltation, vegetation changes, changes of agro crop production, damage of water quality and survival threats to flora and fauna of mangrove species in the Sundarbans region. The hydrology of the lower GBM Delta is dominated by the freshwater flows from upstream Ganges, Brahmaputra and Meghna Rivers, which exhibit very high seasonal variation in their discharge. Tidal influence extends to more than $50 \mathrm{~km}$ inland from the shoreline and surges increase considerably during the cyclonic storms (Gopal and Chauhan 2006). The nature of these threats is dependent on the GBM river system, fresh water supply, geohydrological and ecological characteristics of Ganges deltaic region.

\section{Conclusions}

The tidally active deltaic floodplain and wetlands are highly affected by saline water intrusion in the coastal region. It indicates that salinity intensity gradually increased from north to south and east to west direction in the lower deltaic region. The highest salinity occurs in western part of the Ganges-Brahmaputra tidally active and active deltaic floodplains wetlands region. The soil salinity trend is $>25,452 \mathrm{dS} / \mathrm{m}$, which is a much stronger threat for agricultural crop production in the deltaic wetland region. In the Ganges-Brahmaputra-Meghna Delta about $8600 \mathrm{~km}^{2}$ land area is affected by salinity intrusion. The south and south western part of Bhola, south of Potuakhali, Barguna, Bagerhat, Khulna and Satkhira where soil salinity is $>25,452 \mathrm{dS} / \mathrm{m}$, this rate is harmful for yield production and production rate is $0 \%$ except rice cultivation in the rainy season. $75 \%$ land area of Sathkhira district, $66 \%$ of land area of Bagerhat district and $32 \%$ land area of Khulna district are greatly impacted by water and soil salinity.

The finding of this study shows that the wetlands ecosystems are degrading in the GBM deltaic floodplain regions. The coastal saline water intrudes up to $150 \mathrm{~km}$ inland in the lower Meghna in the south east and up to $190 \mathrm{~km}$ up the Passur River in southwest region of the deltaic floodplain. The management process in the wetland regions in the Ganges delta is not adequate yet, even there is no institutional platform to maintenance the wetland ecosystems in the floodplain areas in Bangladesh. The most important point is that the Ganges-Brahmaputra-Meghna Rivers Delta is responding to a number of pressures and any analysis of the delta for management and planning purposes needs to be an integrated assessment of all these factors, rather than focusing on individual stresses. The available deltaic wetlands planning and development knowledge is narrow and limited, hence it could be harmful to articulate the uncertainty of the deltaic planning, development and sustainable management of its resources.

Vision 2020 is an exclusive national challenging development programme for Bangladesh; therefore deltaic floodplain wetland management as well as policy in general could be included as a fundamental source of natural resources that could be initiated the sustainable deltaic wetland development programme in Bangladesh. The Ganges water supply and policy is consequently a strategic and political topic between Bangladesh and India, for that reason the stable floodplain wetland management is necessary for sustainable deltaic ecosystems in the Ganges delta. This, in turn, could affect the long-term sustainability of GBM floodplain and wetland ecosystems management in the whole region. The deltaic floodplain wetlands should 
be managed properly within an interdisciplinary management approach as they are prospective for the local community and stakeholders. Therefore, wise use of wetland natural resources should be ensured and sustained through the proper implementation of the proposed management framework (Fig. 8). The findings of this study could be used in the preparation phase of a national deltaic floodplain management plan and for the protection of deltaic floodplain wetlands and ecosystems sustainability management in the Ganges-Brahmaputra-Meghna Rivers Delta between Bangladesh and India.

\section{References}

Ahmed R, Falk GC (2008) Bangladesh: environment under pressure. Geogr Rundsch Int Ed 4(1):13-18

Ahmed I, Deaton BJ, Sarker R, Virani T (2008) Wetland ownership and management in a common property Resources setting: A case study of Hakakuki Haor in Bangladesh. Ecol Econ 68(12):429-436

Ahsan M (2001) Prospect of rainwater harvest in farm ponds for irrigation in the coastal saline areas of Bangladesh. In: Proceedings of the annual workshop on soil resources 14-15 February 2001. Soil Resource Development Institute (SRDI), Dhaka, Bangladesh, pp 33-37

Ahsan M, Rahman M (2001). Salinity constraints and agricultural productivity in coastal saline area of Bangladesh. In: Proceedings of the annual workshop on soil resources, 14-15 February 2001. Soil Resource Development Institute (SRDI), Dhaka, Bangladesh, pp 1-14

Akonda AW (1989) Bangladesh. In: Scott DA (ed) A directory of Asian wetlands. IUCN, Gland, pp 541-581

Allee WC, Emerson AE, Thomas OP, Schmidt KP (1949) Principles of animal ecology. W. B. Saunders Co, Philadelphia, pp 1-695

Allison MA (1998) Geologic framework and environmental status of the Ganges-Brahmaputra Delta. J Coast Res 14(4):1269-1275

Allison MA, Kepple EB (2001) Modern sediment supply to the lower delta plain of the Ganges-Brahmaputra River in Bangladesh. J Geophys Res 21:66-74

Allison MA, Khan SR, Goodbred SL, Kuehl SA (2003) Stratigraphic evolution of the late Holocene Ganges-Brahmaputra lower delta plain. Sediment Geol 155:317-342

Anwar J (1988) Geology of coastal area of Bangladesh and recommendation for resource development and management. In: National workshop on coastal area resource development and management, part II. Organized by CARDMA, Dhaka, Bangladesh, pp 36-56

Bagchi K (1944) The Ganges delta. University of Calcutta Press, Calcutta, pp 1-157

Begum K (1987) Tension over the Farakka Barrage-a techno political tangle in South Asia. University Press Limitated, Dhaka, pp 1-298

Benerji RK (1981) Cretaceous-Eocene sedimentation, techtonism and biofacies in the Bengal Basin, India. In: Palaeogo. Palaeocli Palaeoco, pp 34-85

Brammer H (1996) Geographical complexities of detailed impact assessment for the Ganges-Brahmaputra-Meghna Delta of Bangladesh. In: Warrick R, Barrow EM, Wigley TM (eds) Climate and sea level change. Cambridge University Press, Cambridge, pp 263-275
CEGIS - Centre for Environmental and Geographical Information Services (2010) Identification mission K2K, water mondiaal Delta Alliance reconnaissance visit to Dhaka Bangladesh, Mission Report (draft), 20-24 June 2010, Slingerland K Bons $\mathrm{K}$ and Driel WV (eds) Wageningen University and Research Centre, The Netherlands, pp 1-22

Chowdhury ZU, Haque A (1990) Permissible water withdrawal based upon prediction of salt-water intrusion in the Meghna delta. In: The hydrological basin for water resources management (Proceedings of the Beijing symposium, October 1990). IAITS Publ. no. 197 , pp 111-117

Coleman JM (1969) Brahmaputra river channel process and sedimentation. Sediment Geol 3(2-3):129-239

Colombi SB, Bradnock RW (2003) Geopolitics, water and development in south Asia: cooperative development in the GangesBrahmaputra Delta. Geogr J 169(1):43-64

Costanza R, Norton BG, Haskell BD (1992) Ecosystems health: new goals for environmental management. Island Press, Washington, DC

Curray JR, Moore DG (1974) Sedimentary and tectonics and geological processes in Bengal deep sea fan and geosynclines. In: Burk CA, Droke CL (eds) The geology of continental margins. Springer, New York, pp 617-627

Daily G, Reichere JS, Myers JP (1997) Nature's services societal dependence on natural ecosystems. Island Press, Washington, DC

Edwards P, Little D, Demaine H (2002) Rural aquaculture, CABI International, Wallingford Oxford, UK

EGIS-Environmental Geographical Information Services (1997) Morphological dynamics of the Brahmaputra-Jamuna River. Water Resources Planning Organisation/Delf Hydraulicc, Dhaka

EGIS-Environmental Geographical Information Services (2000) Environmental baseline of Gorai river restoration projectenvironment and GIS support project for water sector planning (EGIS-II). Ministry of Water Resources, Government of Bangladesh and Government of the Netherlands, pp 1-150

Elahi KM, Das SC, Sultana S (1998) Geography of coastal environment: a study of selected issues. In: Bayes A, Mahammad A (eds) Bangladesh at 25, an analytical discourse on development. University Press Limited, Dhaka, pp 336-368

Eugene PO (1953) Fundamental of ecology. W. B. Saunder Co, Philadelphia, p 9

FAP 24-(Flood Action Plan 24) (1996). River survey projectmorphology of Gorai off-take: special report no. 10. WARPO, Dhaka

Fergusson J (1863) On recent changes in the Delta of the Ganges. Q J Ged Soc 19:321-354

Goodbred SL, Kuehl SA (1999) Holocene and modern sediment budgets for the Ganges-Brahmaputra river system: evidence for highstad dispersal to floodplain. Shelf Deep Sea Depocent Geol 27(6):559-562

Goodbred SL, Kuehl SA (2000) The significance of large sediment supply, active tectonics, and estuary on margin sequence development: late quarternary stratigraphy and evolution of the Ganges-Brahmaputra delta. Sed Geol 133(3-4):227-248

Goodbred SL, Nicholls R (2004). Towards integrated assessment of the Ganges-Brahmaputra delta. In: Proceeding of the 5th international conference on asian marine geology, and 1st annual meeting of IGCP475 Delta and APN Mega-Delta, 13 Feb, pp 1-15

Gopal B, Chauhan M (2006) Biodiversity and its conservation in the Sundarban mangrove ecosystem. Aquat Sci 68(3):338-354

Gopal B, Wetzel G (1995) Limnology in developing countries, V.I. New Delhi. International Association for Limnology, pp 1-230

Gupta HP (1981) Palaeoenvironments during Holocene time in Bengal basin, India as reflected by palynology. Palaeobotanist 27(2):138-159 
Hoque MM, Alam SMK (1995) Post Farakka dry season surface and groundwater conditions in the Ganges water and vicinity. In: Hasna JM (ed) Women for water sharing. Academic Publishers, Dhaka, pp 1-22

Helmer R, Hespanhol I (eds) (1997) Water pollution control. A guide to the use of water quality management principles. E \& FN SPON, London, pp 304-316

Hoper T (1998) Floods in Bangladesh: a highland lowland interaction. Dissertation for the Doctoral Degree. Department of Geography, Switzerland, University of Bern, Switzerland, pp 22-62

Hunter WW (1894) Atlas of India, map I. W and A. K. Johnston, Lower Bengal, Edinburgh, London

Hughes R, Adnan s, Clayton BD (1994) Floodplains or flood plann? A review of approaches to water management in Bangladesh. IIED, London, UK, pp 1-12

ISPAN - Irrigation Support Project for Asia and the Near East (1995) The dynamic physical and human environment of riverine charlands: Brahmaputra-Jamuna, Bangladesh Flood Action Plan, Ministry of Water Resources Flood Plan Coordination Organization (FPCO), Prepared by FAP 16 and FAP 19, Dhaka and ISPAN Technical Support Center, Arlington, Virginia, USA, pp 1-160

Islam A (1995) Environment land use and natural hazards in Bangladesh. University of Dhaka, Dhasheree Mudrayan, Nilkhet, Dhaka

Islam MS (2001) Sea-level changes in Bangladesh: the last ten thousand years. Asiatic Society of Bangladesh, Asiatic Civil Military Press, Dhaka, pp 1-185

Islam S (ed) (2006) Encyclopedia of Bengal. Asiatic Society of Bangladesh, Asiatic Civil Military Press, Dhaka

Islam SN (2010) Threatened wetlands and ecologically sensitive ecosystems management in Bangladesh. Front Earth Sci China 4(4):438-448

Islam SN, Gnauck A (2007) Increased salinity in the Ganges delta and impacts on coastal environment in Bangladesh. In: proceeding of logistics and economic of resource and energy-saving in industries, 12-15 Sept. ISPC, Saratov State Technical University, Saratov, Russia, pp 244-248

Islam SN, Gnauck A (2008) Mangrove wetland ecosystems in Ganges-Brahmaputra delta in Bangladesh. Front Earth Sci China 2(4):439-448

Islam SN, Gnauck A (2009a) Threats to the Sundarbans mangrove wetland ecosystems from transboundary water allocation in the Ganges basin: a preliminary problem analysis. In: Saeid E (ed) International Journal of Ecological Economics and Statistics (IJEES), 13(09):64-78

Islam SN, Gnauck A (2009b). The coastal mangrove wetland ecosystems in the Ganges delta: a case study on the Sundarbans in Bangladesh. In: Proceeding of American Association of Petroleum Geologist-AAPG Hedberg conference on variations in fluvial-deltaic and coastal reservoirs deposited in tropical environments, from 29th April 2nd May, 2009, Jakarta, Indonesia, pp 26-29

Islam SN, Karim R, Islam AN, Eslamian S (2014a) Wetland hydrology (chapter 29). In: Handbook of engineering hydrology, environmental hydrology and water management, vol. 3. Taylor \& Francis, pp 582-605

Islam SN, Gnauck A, Voigt H-J, Eslamian S (2014b). Hydrological changes in mangrove ecosystems (chapter 18). In: Handbook of engineering hydrology, modeling, climate change and variability, vol. 2. Taylor \& Francis, pp 356-373

Joseph PS (2006) The environmental management the better supply of fresh water in transboundary river: the Ganges could run dry. In: Perez JG (ed) Proceedings of III international symposium on transboundary waters management-overcoming water management boundaries. Universidad de Castilla-La Mancha. 30 May-2 June, Ciudad Real, Spain
Khan FH (1991) Geology of Bangladesh. University Press Limited, Dhaka

Khan AA (1993) Freshwater wetlands in Bangladesh: Opportunities and options. In: Nishat A, Hussain Z, Roy MK, Karim A (eds) Freshwater wetlands in Bangladesh issues and approaches for management, IUCN, Dhaka

Khan SR, Islam MB (2008) Holocene stratigraphy of the lower Ganges-Brahmaputra river delta in Bangladesh. Front Earth Sci China 2(4):393-399

Khan SM, Haq E, Hug S, Rahman AA, Rashid SMA, Ahmed H (1994) Wetlands of Bangladesh. Holyday Printers, Dhaka pp 1-88

Khandoker RA (1987) Origin of elevated Barind-Madhupur areas, Bengal Basin, result of neotectonicactivities, Bangladesh. J Geol 6(2):1-9

Kudrass HR, Spiessv V, Michels M, Kottke B, Khan SR (1999) Transport processes, accumulation rates and a sediment budget for the submarine delta of the Ganges-Brahmaputra and the swatch of no-ground, Bangladesh. International seminar on the quaternary development and coastal hydrodynamics of the Ganges delta in Bangladesh, Geological Survey of Bangladesh, Dhaka, 20-21 Sept

Lindsay JF et al (1991) Sequence stratigraphy and the evolution of the Ganges-Brahmaputra delta complex. Am Assoc Pet Geol Bull 75

Mafizuddin M, Ali MM (1993) Alluvial characteristics of the changes floodplain. Journal Bangladesh Natl Geogr Assoc (BNGA) 19(12): $1-12$

MEA-Millennium Ecosystem Assessment (2005a) Ecosystems and human well-being synthesis. Millennium Ecosystem Assessment (MEA), Island Press, New York

MEA-Millennium Ecosystem Assessment (2005b) Living beyond our means: natural assets and human well-being. Statement of the MA board. Millennium Ecosystem Assessment (MEA), Island Press, New York

Miah MA (2001) Effect on water resources from upstream water diversion in the Ganges Basin. J Environ Qual 30(2):356-368

Milliman JD, Broadus JM, Gable F (1989) Environmental and Economic implications of raising sea level and subsiding deltas: The Nile and Bengal examples. Ambio 18(6):340-345

Morgen JP, Mclntire WG (1959) Quaternary geology of the Bengal Basin, East Pakistan and India. Bull Geol Soc Am 70:319-342

Nair KS (2004) Wetlands management to meet the food and water crisis- In: Abtracts book of 7th INTECOL, International conference on wetlands, 25-30 July 2004. Utrecht, The Netherlands, pp 1-217

Nishat A (1988) Review of present activities and state of art of the coastal area of Bangladesh. In: National workshop on coastal area resource development and management, part II. Organized by CARDMA, Dhaka, Bangladesh, pp 23-35

Nishat A (2006) Water at Farakka Barrage in 2006. http://www. ajkerkagoj.com/2006/April. Accessed 10 March 2012

Niyogi D (1975) Quaternary geology of the coastal plain in West Bengal and Orissa. Ind J Earth Sci 2(1):51-61

Rahman AA (1988) Bangladesh coastal environment and management. In: Hasna MJ, Rashid HE, Rahman AA (eds) National workshop on coastal area resource development and management. Academic Publishers, CARDMA, Dhaka, pp 1-22

Ravenscroft P (2003) An overview of the hydrogeology of Bangladesh. In: Rahman AA, Ravenscroft P (eds) Groundwater resources and development in Bangladesh. Bangladesh Centre for Advanced Studies, University Press Ltd, Dhaka

Rennel J (1793) Memoir of a map of Hindoostan: or Mogul Empire (with appendix containing and account of the Ganges and Brahmaputra rivers), 3rd edn. W. Bulmer and Co, London

Rob MA (1998) Changing morphology of the coastal region of Ganges delta. Orient Geogr 41(2):49-64 
Sarker SU (1993) Faunal diversity and their conservation in freshwater wetlands. In: Freshwater Wetlands in Bangladesh: Issues and approaches for management Gland: IUCN, Switzerland, pp 1-364

Sarker MH (2008) Morphological response of the BrahmaputraPadma-lower Meghna River system to the Assam Earthquake of 1950. Unpublished Ph.D. thesis, School of geography, University of Nottingham, UK, pp 1-296

Sarker MH, Huque I, Alam M, Koudstaal R (2003) Rivers, chars and char dwellers of Bangladesh. Int $\mathrm{J}$ River Basin Manag 1(1):61-80

Sarker MH, Klassen GJ, Noor F, Islam SM (2011) Impact of the Bangabandhu Bridge on the Morphology of the Jamuna River, Bangladesh. In: Proceeding of the 3rd International conference on water and flood management, ICWFM-2011, Dhaka, Swasti Printers, Nilkhet, vol. 1 pp 325-338

Schmuck WS (2001) Facing the Jamuna river-indigenous and engineering knowledge in Bangladesh. Bangladesh Resource Centre for Indigenous Knowledge (BARCIK), Dhaka, Bersha (Pvt) Ltd, Nilkhet, pp 1-242
Scoons L (1998) Sustainable rural livelihoods: A framework for Analysis, IDS working paper 72, University of Sussex, Brighton, UK, pp 1-22

SRDI-Soil Resource Development Institute (2000) Soil salinity in Bangladesh. Government of the People's Republic of Bangladesh. Soil Resource Development Institute, Dhaka

Umitsu M (1993) Late quaternary sedimentary environments and landforms in the Ganges delta. Sed Geol 83(3-4):177-186

Wilcox R (1830) Map of the Brahmaputra and Ichamati River, Reduced and drawn by M.H Dias, India office Library and Records, London

Woodroffe CD, Nicholls RJ, Saito Y, Chen Z, Goodbred SL (2006) Landscape variability and the response of Asian mega deltas to environmental change. In: Harvey $\mathrm{N}$ (ed) Global change and integrated coastal management. Springer, Berlin, pp 277-314

Zube EH (1986) Landscape values: history, concepts and applications. In: Smardon P, Felleman JP (eds) Foundation for visual project analysis. Wiley, New York, pp 4-19 